\title{
Possible Role of Superoxidised Water in the Treatment of Trichophyton Infections: An In vitro Study
}

\author{
Munesh K. Gupta, Soni Sinha, Nidhi Pandey, Pradyot Prakash and Ragini Tilak* \\ Department of Microbiology, Institute of Medical Sciences, Banaras Hindu University, Varanasi - 221005 , India.
}

\begin{abstract}
Superficial fungal infections are the common health seeking problem. These fungal infections are caused by three genera of Dermatophytes, naming Trichophyton, Microsporum, Epidermophyton. Among these three, Trichophyton spp. causes most of these lesions. Trichophyton spp. primarily infect the moist areas of human bodies. Different groups of antifungal agents are used in the treatment of these fungal infections. Despite availability of antifungal treatment, an increasing number of recurrent superficial fungal infections have been reported. We assessed the antidermatophytic activity of superoxidised water; a newer disinfectant, against Trichophyton spp. isolated from the cutaneous fungal infections. A total of 79 isolates of Trichophyton species including mentagrophytes $(n=43)$ and rubrum $(n=32)$ were exposed to freshly generated superoxidised water. A 50 $\mu$ l of $0.1 \mathrm{OD}$ of the Trichophyton conidia were

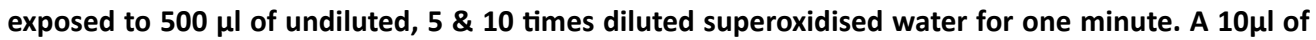
these exposed conidia were inoculated on SDA. A 10 $\mu$ l of conidia (no exposure to superoxidised water) was also inoculated on SDA tube. Tubes were incubated at $28^{\circ} \mathrm{C}$ in BOD incubator. No growth was observed in tubes having exposed conidia only to undiluted Superoxidised water, even after the 28 days of continuous incubation at $28^{\circ} \mathrm{C}$. Growth within 7 days was observed in the tubes having unexposed conidia and exposed to dilute Superoxidised water. Undiluted superoxidised water showed the In vitro inhibition on Trichophyton mentagrophytes and Trichophyton rubrum which might be useful in future in the treatment of these infections.
\end{abstract}

Keyword: Dermatophyte, Superoxidised water, Trichophyton, Disinfection, Skin, Sterisol.

*Correspondence: raginijain29@rediffmail.com; 91-9415812317

(Received: 23 March 2019; accepted: 15 May 2019)

Citation: Munesh K. Gupta, Soni Sinha, Nidhi Pandey, Pradyot Prakash and Ragini Tilak, Possible Role of Superoxidised Water in the Treatment of Trichophyton Infections: An In vitro Study, J Pure App/ Microbiol., 2019; 13(2): 887-890. doi: 10.22207/JPAM.13.2.24

(c) The Author(s) 2019. Open Access. This article is distributed under the terms of the Creative Commons Attribution 4.0 International License which permits unrestricted use, sharing, distribution, and reproduction in any medium, provided you give appropriate credit to the original author(s) and the source, provide a link to the Creative Commons license, and indicate if changes were made. 


\section{INTRODUCTION}

Dermatophyte infections of the skin, hair, and nail are the common cutaneous fungal infection ${ }^{1}$. These dermatophytes primarily infect the moist areas of the human body such as groin, armpits, scalp, sub-mammary area where they result in a different clinical manifestation as Tinea cruris, Tinea capitis, Tinea pedis etc ${ }^{2,3}$. Three genera of dermatophyte; Trichophyton, Microsporum, and Epidermophyton, cause these fungal infections. Trichophyton spp. infects the skin, hair, and nail whereas Microsporum spp. infect the skin \& hair. Epidermophyton sp. infects the skin and nail. Most of the human dermatophyte infections have been reported due to Trichophyton mentagrophytes and T.rubrum².

A different group of the antifungal agents is used in the treatment of these dermatophyte infections. These antifungal drugs either inhibit the ergosterol synthesis, the major component of the fungal cell wall or inhibit the functional activity of the microtubules ${ }^{4,5,6}$. Although these antifungal drugs are quite effective in the treatment of these fungal infections but in the present decade, a large number of non-responding dermatophyte infections has been reported from different regions of India. Thus there is a need for a newer effective treatment for these infections.

Superoxidised water (SOW) is a newly disinfectant which is generated by the electrochemical activation. It is a mixture of different oxidizing agents containing hypochorous acid and sodium hypochlorite with $\mathrm{pH}$ of 5.0-6.5. Superoxidised water is bactericidal, fungicidal, virucidal and sporicidal solution? ${ }^{7}$. Free radical, produced during the oxidation-reduction process, denature the protein of bacterial cell wall. It also impairs the solute transport as well as the salt balance, resulting in the cell lysis ${ }^{8}$. Potent disinfectant role of superoxidised water against bacteria and molds has been reported by different authors but, Best of our knowledge, no in vitro study has been conducted against the dermatophytes $^{9-11}$. Against this background, we assessed the in-vitro activity of superoxidised water (SOW) against the dermatophytes isolated from skin lesions.

\section{MATERIALS AND METHODS}

Disinfectant property of freshly generated SOW (sterisol), generated by SteriGen ${ }^{\circledR}$ disinfectant generating system, was assessed against 79 Trichophyton species strains isolated from cutaneous lesions. These Trichophyton spp. were subcultured on potato dextrose agar and kept at $35^{\circ} \mathrm{C}$ for 7 days. The conidia were harvested with the tween 20 \& normal saline and $0.10 D$ conidial suspension was prepared. $50 \mu$ l of this conidial suspension was exposed to the $500 \mu \mathrm{l}$ of the freshly generated SOW, and $5 \& 10$ times diluted SOW. After exposure of one minute, a $10 \mu \mathrm{l}$ suspension was inoculated on SDA tube. A $10 \mu \mathrm{l}$ of the unexposed conidial suspension was also inoculated on the SDA tube as a growth control. These tubes were incubated at $28^{\circ} \mathrm{C}$ and observed for the growth.

\section{RESULTS}

A total of 79 dermatophyte strains, including 43 strains of $T$. mentagrophytes, 32 strains of $T$. rubrum, and 4 Trichophyton spp. were included in the present study. Both the SDA

Table1. Effect of SOW on different Trichophyton species isolated from superficial fungal infections

\begin{tabular}{lcccc}
\hline Dermatophytes & \multicolumn{3}{c}{ Freshly generated SOW } \\
\cline { 2 - 5 } & Control & $\begin{array}{c}\text { Exposure to } \\
\text { undiluted SOW }\end{array}$ & $\begin{array}{c}\text { Exposure to 5 times } \\
\text { diluted SOW }\end{array}$ & $\begin{array}{c}\text { Exposure to 10 times } \\
\text { diluted SOW }\end{array}$ \\
\hline $\begin{array}{l}\text { T. mentagrophytes } \\
(\mathrm{n}=43)\end{array}$ & + & - & + & + \\
$\begin{array}{l}\text { T.rubrum ( }=32) \\
\text { Trichophyton spp. } \\
(\mathrm{n}=4)\end{array}$ & + & - & + & + \\
\hline
\end{tabular}

Note: Growth inhibition (-); No Growth inhibition (+) 


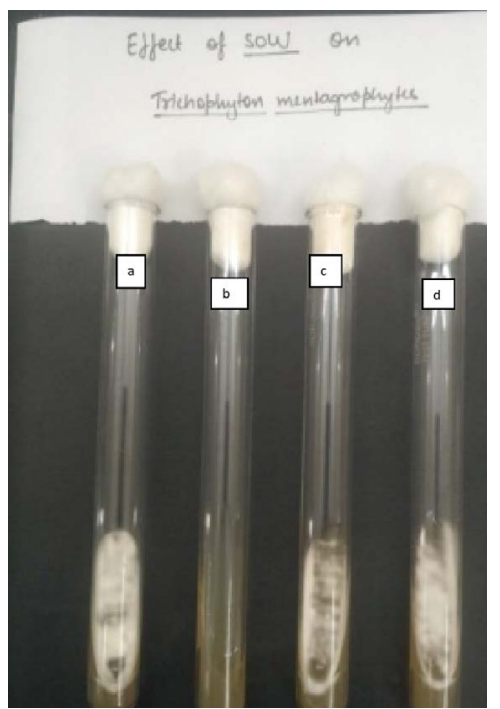

Fig. 1. Effect of different dilution of Sow on T.mentagrophyte. (a): control tube; no exposure to SOW, (b) no growth after exposure to undiluted SOW, (c) growth after exposure to 5 times diluted SOW, (d) growth after exposure to 10 times diluted SOW

tubes containing $10 \mu$ l of exposed and non exposed conidia were examined for the growth. The tubes were read daily in the $1^{\text {st }}$ week, on every $2^{\text {nd }}$ day in the second week, every $3^{\text {rd }}$ day in the third week and final results were observed at 28 days. In control tubes, growth was observed between 5-10 days whereas no growth was observed in SDA tubes, containing exposed conidia to undiluted superoxidised water, even after 28 days of continuous incubation. Complete inhibition of all Trichophyton spp. was only observed in the tube containing conidia suspension, exposed to undiluted SOW whereas in tubes having diluted sow exposed conidia, growth was observed. (Table 1, Fig. 1)

\section{DISCUSSION}

Trichophyton infections are the major superficial fungal infection to which a dermatologist encounters most frequently in their OPDs. These Trichophyton spp. primarily infect the moist areas of the human body where moisture provides the favorable environment for the growth of these dermatophytes ${ }^{2}$. These Trichophyton spp. infect most superficial layers of skin, hair, and nail where they release the keratinase enzyme which helps in its invasion. ${ }^{12}$ In skin lesion, caused by Trichophyton spp., a red erythematous lesion with central clearing is observed which constantly increase in size. Itching at the margin of the lesion is a cardinal feature of such fungal infections. Infected hair becomes dry, atrophied and may result in alopecia. The infected nail becomes brittle, dried and discolored.

Treatment of these dermatophyte infections is very difficult and time taking. For the treatment of these dermatophyte infections, oral or topical antifungal agents either in the form of a cream or an ointment are used. Most of these antifungal agents are used topically whereas other drugs as itraconazole, griseofulvin and terbinafine are used orally as these drugs concentrate in the $\operatorname{skin}^{13,14}$.

Superoxidised water (SOW) is a newer disinfectant which has the ability to kill the microbes within the seconds of exposure. In previous studies, its efficacy has been assessed against the different bacterial and fungal pathogens including yeast and filamentous fungi ${ }^{9}$. In this present study, we assessed the efficacy of the freshly generated SOW against the Trichophyton spp. isolated from different clinical samples where complete growth inhibition was observed after the exposure to the only undiluted SOW.

Superoxidised water (SOW), FDA approved product, is generated by oxidationreduction reaction where normal saline is passed over the titanium coated electrode at a current of 6-9amp. This SOW contains a mixture of oxidizing substance including hypochlorus and sodium hypochlorite in equilibrium. This solution with a $\mathrm{pH}$ of 5-6, is non-hazardous to the skin, non-irritating to the eyes. These all feature favor its use in the treatment of cutaneous fungal infections ${ }^{7,15}$.

SOW is being frequently used in the dressing of the wound where it has been shown to enhance the granulation of the infected wound. In a study, published by Kapur et al, reported that use of the SOW resulted in early healing with reduced inflammation ${ }^{8}$. Similar results on wound healing have been reported by Sharma et $\mathrm{al}^{16}$. A meta-analytic study by Eftekharizadeh et al also reported the SOW as a safe, effective, costeffective irrigation and cleaning agent ${ }^{17}$. Although this study provides a satisfactory in-vitro activity but also the results should be evaluated in vivo which necessitate a clinical trial. 


\section{CONCLUSION}

In vitro complete inhibition of the Trichophyton spp., by the freshly generated superoxidised water, might open a new era in the treatment of superficial fungal infection as it is economical, safe, non-irritating, non-allergic to the skin.

\section{ACKNOWLEDGMENTS}

We are sincere thankful to Department of dermatology and venerology for their support to present study.

\section{CONFLICTS OF INTEREST}

The authors declare that there in no conflict of interest.

\section{AUTHOR CONTRIBUTION}

All authors listed have made a substantial, direct and intellectual contribution to the work, and approved it for publication.

\section{FUNDING SOURCE}

None.

\section{DATA AVAILABILITY}

All the generated/analyzed dataset has been included in manuscript.

\section{ETHICAL STATEMENT}

Not applicable.

\section{REFERENCES}

1. Weitzman I., Summerbell R.C. The dermatophytes. Clin. Microbiol. Rev., 1995; 8: 240-59.

2. Lacaz C.S., Porto E., Martins J.E.C., Heins-Vaccari E.M., Melo N.T. Tratado de Micologia M'dica Lacaz, 2002, Pp. 252-340. $9^{\text {th }}$ ed. STo Paulo Sarvier.

3. Hay R.J., Ashbee H.R. Superficial mycoses, 2010, pp. 36.5-36.68. Burns T., Breathnach S., Cox N., Griffiths C., editors. Rook's Textbook of Dermatology. $8^{\text {th }}$ Singapore: Wiley Blackwell.

4. Hitchcock C., Dickinson K., Brown S.B., Evans E.G., Adams D.J. Interaction of azole antifungal antibiotics with cytochrome P450-dependent $14 \alpha$-sterol demethylase purified from Candida albicans. J.
Biochem., 1990; 266: 475-80

5. Ryder N.S. Terbinafine: mode of action and properties of the squalene epoxidase inhibition. Br. J. Dermatol., 1992;126(39):2-7

6. Roobol A., Gull K., Pogson C.I. Inhibition by griseofulvin of microtubule assembly in vitro. FEBS Lett., 1976; 67(3): 248-51

7. BLOOMFIELD SF. Chlorine and iodine formulations, 1996, Pp.147-53. Joseph M Ascenzi. Handbook of disinfectants and antiseptics. $1^{\text {st }}$ Ed. New York : M. Dekker

8. Kapur V., Marwaha A.K. Evaluation of effect and comparison of superoxidised solution (oxum) v/s povidone iodine (betadine). Indian Journal of surgery, 2011; 73(1): 48-53.

9. Gupta M.K., Prakash P., Bharti S., Paswan A.K., Singh D.K., Tilak R. Superoxidised water: A promising disinfectant against bacterial and fungal pathogens. Annals of Pathology and Laboratory Medicine, 2017; 4(1): A19-22.

10. Shetty N., Srinivasan S., Holton J., Ridgway G.L. Evaluation of microbicidal activity of a new disinfectant: Sterilox ${ }^{\circledR} 2500$ against Clostridium difficile spores, Helicobacter pylori, vancomycin resistant Enterococcus species, Candida albicans and several Mycobacterium species. Journal of Hospital Infection, 1999; 41(2): 101-5.

11. Choi T.Y., Yang E.Y. Bactericidal Effect of Medilox, an super oxidized water generated by Medilox against Bacteria, Fungi and Mycobacteria. J. Soonclumhvcing Med. Science, 2009; 14(3): H5-794.

12. Muhsin T.M., Hadi R.B. Degradation of keratin substrates by fungi isolated from sewage sludge. Mycopathologia, 2002; 154(4): 185-9.13

13. Degreef H.J., DeDoncker P.R. Current therapy of dermatophytosis. J. Am. Acad. Dermatol., 1994; 31(3 Pt 2): S25-30

14. Noppakun N., Phuphaibool K. Treatment of dermatophytosis with new systemic antifungal agent, itraconazole. J. Med. Assoc. Thai., 1992; 75(2): 99-103

15. Selkon J., inventor; Sterilox Medical (Europe) Ltd, assignee. Super-oxidized water, preparation and use thereof as sterilizers and medicaments. United States patent application US 10/084, 518. 2002.

16. Sharma N., Mishra T.S., Singh S., Gupta S. Evaluation of effect and comparision of superoxidised solution (oxum) v/s povidone iodine (betadine): points to ponder. Indian J. Surg., 2012; 74(6): 493

17 Eftekharizadeh F., Dehnavieh R., Noori Hekmat S., Mehrolhassani M.H. Health technology assessment on super oxidized water for treatment of chronic wounds. Medical Journal of the Islamic Republic of Iran, 2016; 30: 384. 